\title{
Changes in serum and synovial fluid biomarkers after acute injury (NCT00332254)
}

\author{
Jonathan B Catterall', Thomas V Stabler', Carl R Flannery², Virginia B Kraus*
}

\begin{abstract}
Introduction: Acute trauma involving the anterior cruciate ligament is believed to be a major risk factor for the development of post-traumatic osteoarthritis 10 to 20 years post-injury. In this study, to better understand the early biological changes which occur after acute injury, we investigated synovial fluid and serum biomarkers.

Methods: We collected serum from 11 patients without pre-existing osteoarthritis from a pilot intervention trial (5 placebo and 6 drug treated) using an intra-articular interleukin-1 receptor antagonist (IL-1Ra) therapy, 9 of which also supplied matched synovial fluid samples at presentation to the clinic after acute knee injury (mean $15.2 \pm 7.2$ days) and at the follow-up visit for reconstructive surgery (mean $47.6 \pm 12.4$ days). To exclude patients with preexisting osteoarthritis $(\mathrm{OA})$, the study was limited to individuals younger than 40 years of age (mean $23 \pm 3.5$ ) with no prior history of joint symptoms or trauma. We profiled a total of 21 biomarkers; 20 biomarkers in synovial fluid and 13 in serum with 12 biomarkers measured in both fluids. Biomarkers analyzed in this study were found to be independent of treatment $(P>0.05)$ as measured by Mann-Whitney and two-way ANOVA.

Results: We observed significant decreases in synovial fluid (sf) biomarker concentrations from baseline to followup for ${ }_{5 f} C$-Reactive protein (CRP) $(P=0.039)$, sf lubricin $(P=0.008)$ and the proteoglycan biomarkers:

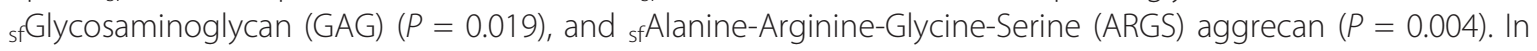
contrast, we observed significant increases in the collagen biomarkers: ${ }_{5 f} C$-terminal crosslinked telopeptide type II collagen $(C T x \mid I)(P=0.012)$, sf $C 1,2 C(P=0.039)$, sf $C$-terminal crosslinked telopeptide type I collagen $(C T x \mid)(P=0.004)$, and ${ }_{\text {sf }} \mathrm{N}$-terminal telopeptides of type I collagen $(\mathrm{NTX})(P=0.008)$. The concentrations of seven biomarkers were significantly higher in synovial fluid than serum suggesting release from the signal knee: IL-1 $\beta(P<0.0001)$, fetal aggrecan FA846 ( $P=0.0001), C T x I(P=0.0002)$, NTx $(P=0.012)$, osteocalcin $(P=0.012)$, Cartilage oligomeric matrix protein (COMP) $(P=0.0001)$ and matrix metalloproteinase $(M M P)-3(P=0.0001)$. For these seven biomarkers we found significant correlations between the serum and synovial fluid concentrations for only $C T x I(P=0.0002)$, NTx $(P<0.0001)$, osteocalcin $(P=0.0002)$ and MMP-3 $(P=0.038)$.
\end{abstract}

Conclusions: These data strongly suggest that the biology after acute injury reflects that seen in cartilage explant models stimulated with pro-inflammatory cytokines, which are characterized by an initial wave of proteoglycan loss followed by subsequent collagen loss. As the rise of collagen biomarkers in synovial fluid occurs within the first month after injury, and as collagen loss is thought to be irreversible, very early treatment with agents to either reduce inflammation and/or reduce collagen loss may have the potential to reduce the onset of future posttraumatic osteoarthritis.

Trial registration: The samples used in this study were derived from a clinical trial NCT00332254 registered with ClinicalTrial.gov.

\footnotetext{
* Correspondence: vbk@duke.edu

${ }^{1}$ Division of Rheumatology, Department of Medicine, Duke University, Genome Science Research Building I, 905 South LaSalle Street, Durham, NC 27710, USA

Full list of author information is available at the end of the article
}

\section{Biomed Central}

(c) 2010 Catterall et al.; licensee BioMed Central Ltd. This is an open access article distributed under the terms of the Creative Commons Attribution License (http://creativecommons.org/licenses/by/2.0), which permits unrestricted use, distribution, and reproduction in any medium, provided the original work is properly cited. 


\section{Introduction}

Acute trauma to the anterior cruciate ligament (ACL) or meniscus has recently been demonstrated to be a major risk factor for the development of osteoarthritis (OA) with a $50 \%$ chance of a patient developing symptomatic OA 10 to 20 years post-injury repair [1]. ACL injuries represent a quarter of all knee injuries with an annual incidence of at least 81 per 100,000 population which equates to at least 246,000 ACL injuries and more than 175,000 reconstructions in the US annually among persons aged 10 to 64 years old [2]. Knee injury is a leading cause of OA in young people, with young women having a three- to five-fold higher risk of an ACL injury than young men $[1,3]$. A prospective study of young adults revealed a $14 \%$ cumulative incidence of self-reported knee OA by the age of 65 years for those who had any knee injury during their adolescence or young adulthood compared with a $6 \%$ incidence for those without a history of knee joint injury [4]. Post-traumatic OA is believed to account for up to 5.6 million per year or $12 \%$ of the total US cases of symptomatic OA with an estimated cost in 2006 of $\$ 3.06$ billion per year or $0.15 \%$ of total US direct health care costs [5,6]. It is increasingly believed that the development of later $\mathrm{OA}$ in the injured joints is initiated by both bone and cartilage damage caused during the initial traumatic and inflammatory event coupled with possible long term changes to joint loading. After injury, it is proposed that abnormal joint motion and loading lead to a biological response dominated by catabolic activity [1,7]. However, unlike primary OA, post-traumatic secondary OA is initiated by intra-articular pathogenic processes with a known date of onset, namely the date of joint injury. This makes it much more amenable to early intervention than primary OA whose onset is not clearly definable at this time.

Following acute trauma, an initial flare of cytokines has been reported which mirrors that seen in wound healing and includes tumor necrosis factor (TNF) $\alpha$, interleukin (IL)-1 $\beta$, IL-6, IL-8, IL-1 receptor antagonist (IL-1Ra) and IL-10 [8]. Cartilage damage has been demonstrated by the release of proteoglycan and collagen fragments after ACL rupture $[9,10]$; release is maximal in the first few weeks but can persist at a significantly elevated concentration in synovial fluid for decades following injury [10-15]. Other matrix molecules such as matrix metalloproteinase (MMP)-3, tissue inhibitor of metalloproteinase (TIMP)-1 and cartilage oligomeric matrix protein (COMP) have also been demonstrated to have persistently elevated concentrations in synovial fluid after ACL injury $[15,16]$ The increased matrix turnover may not be limited to merely the affected knee as there is evidence to suggest that the concentrations of aggrecan, COMP and MMP-3 are also elevated in the uninjured contralateral knee of ACL rupture patients [17], possibly as a consequence of altered loading. A canine ACL rupture model of OA also demonstrates increased synthesis and turnover of proteoglycan in early arthritis $[18,19]$. Thus, biomarker profiles could potentially indicate risk for progression to OA based on the identities, quantities, and temporal patterns of expression of specific joint tissue components. In this study we investigated a wide range of synovial fluid and serum biochemical biomarkers, at two time points, to better understand the changes and damage which occur to both the bone and cartilage early in the course of severe knee trauma. Many biomarkers are not specific for the joint and there is a possibility that the concentrations of a particular biomarker, when measured in the serum, could be affected by release from alternative sites due to increased systemic inflammation following acute injury. Therefore, in this study we also investigated the relationship between the serum and synovial fluid concentrations of individual biomarkers to determine whether measurements made in the serum reflect the concentrations observed within the signal knee.

\section{Materials and methods Sample collection}

All samples were collected with informed consent and this research was performed with the approval of the Duke University Investigational Review Board and was carried out in compliance with the Helsinki Declaration. Synovial fluid and matched serum samples were collected at baseline (within four weeks of injury) and at follow-up at the time of arthroscopic repair surgery. Synovial fluid was centrifuged $\left(8^{\circ} \mathrm{C}, 3,500 \mathrm{~g}\right.$, five minutes), and the supernatant aliquoted and frozen at $-80^{\circ} \mathrm{C}$ within two hours of collection. Serum was also aliquoted and frozen at $-80^{\circ} \mathrm{C}$ until analysis.

\section{Patient characteristics}

Samples for this study were derived from a randomized double-blinded placebo-controlled pilot trial of a single injection of the short-acting intra-articular IL-1Ra therapy, anakinra, administered at the time of presentation to the clinic [20]. The samples used in this study were derived from a clinical trial, NCT00332254 registered with ClinicalTrial.gov. The trial consisted of 11 patients, 5 saline injected placebo and 6 anakinra injected study participants. We collected serum from 11 patients, 9 of which also supplied matched synovial fluid samples (4 placebo and 5 drug), who presented to the Duke Sports Medicine clinic with a history of recent (within the previous month) severe knee injury due to sports injury. 
The cohort was young and otherwise healthy with a mean age at enrollment of $23 \pm 3.5$ years and a $6 / 5$ male/female split. The study was limited to individuals younger than 40 years of age with no prior history of joint symptoms or trauma to exclude patients with preexisting OA. Patients were enrolled as soon after initial injury as possible with a mean baseline enrollment time of $15.2 \pm 7.2$ days after injury and a mean follow-up time of $47.6 \pm 12.4$ days after injury with samples collected at time of surgery. The joint pathology was defined by clinical knee magnetic resonance images obtained prior to the baseline assessments, and included, in addition to evidence of ACL tear in all patients, other knee joint tissue damage including bone contusions, medial collateral ligament tears, meniscal tears and chondral defects. All biomarkers within this report were found to be independent of treatment by both two-way Analysis of Variance (ANOVA) and by Mann-Whitney tests, so for the purposes of statistical analysis, we combined the drug and control groups to improve statistical power.

\section{Biomarker analyses}

We investigated a range of biomarkers summarized in Table 1 . The majority of biomarker measurements were obtainable with commercially available reagents and assays were performed as per the manufacturer's instructions (details in Table 1). The remaining biomarker assays utilized methods that have been previously described and summarized briefly below.

\section{sGAG determination using alcian blue}

A commercial sGAG kit was used as per the manufacturer's instructions (Kamiya Biomedical Company, Seattle, WA, USA). Briefly, $50 \mu$ of each sample (either standard or synovial fluid) was adjusted to $4 \mathrm{M}$ guanidine- $\mathrm{HCl}$ by addition of an equal volume of $8 \mathrm{M}$ guanidine- $\mathrm{HCl}$, mixed and incubated at room temperature (RT) for 15 minutes. A further $50 \mu \mathrm{l}$ of a $0.3 \%$ volume/volume (v/v) $\mathrm{H}_{2} \mathrm{SO}_{4}$ and $0.75 \% \mathrm{v} / \mathrm{v}$ Trition $\mathrm{X}-100$ solution was added, mixed and incubated at RT for 15 minutes. After incubation, $750 \mu \mathrm{l}$ of alcian blue solution $(0.03 \mathrm{M}$ Guanidine- $\mathrm{HCl}, 0.1 \% \mathrm{v} / \mathrm{v}$ $\mathrm{H}_{2} \mathrm{SO}_{4}, 0.25 \% \mathrm{v} / \mathrm{v}$ triton X-100) was added, mixed and incubated for 15 minutes at RT before centrifugation at $12,000 \mathrm{~g}$ for a further 15 minutes. The supernatant was discarded and $500 \mu \mathrm{l}$ of dimethyl sulfoxide solution (40\% v/v DMSO, $0.05 \mathrm{M} \mathrm{MgCl}_{2}$ ) added and mixed for 15 minutes at RT before centrifugation at 12,000 g for 15 minutes. The supernatant was discarded and the pellet redissolved in Gu-Prop solution (4 M Guanidine$\mathrm{HCl}, 33 \% \mathrm{v} / \mathrm{v} 1$-propanol, $0.25 \% \mathrm{v} / \mathrm{v}$ triton X-100) for 15 minutes on a shaker. Samples were read at $595 \mathrm{~nm}$ and the GAG level determined from a linear standard curve (12.5 to $400 \mu \mathrm{g} / \mathrm{ml}$ ).

Table 1 Summary and sources of the assays used in this study

\begin{tabular}{|c|c|c|c|c|}
\hline Analyte & Details & Assay (Reference) & Sample & Supplier \\
\hline $\mathrm{IL}-1 \beta$ & Inflammatory Cytokine & ELISA [8] & SF, Serum & R\&D Systems, Minneapolis, MN \\
\hline hsCRP & Inflammatory marker & ELISA [43] & SF, Serum & United Biotech, Inc, Mountain View, CA \\
\hline Sulphated GAG & Total proteoglycan loss (mainly aggrecan) & Chemical assay & SF & Kamiya Biomedical Company, Seattle, WA \\
\hline ARGS-aggrecan & Aggrecan cleavage assay & ELISA [21] & SF & Pfizer In house \\
\hline FA846 & Fetal aggrecan matrix protein (CS846 epitope) & ELISA & SF, Serum & IBEX, Montreal, Quebec, Canada \\
\hline CS846 & Aggrecan epitope & Competitive ELISA [43] & Serum & IBEX, Montreal, Quebec, Canada \\
\hline $\mathrm{C} 2 \mathrm{C}$ & Collagenase neoepitope of Collagen ॥ & ELISA [43] & SF, Serum & IBEX, Montreal, Quebec, Canada \\
\hline CTxll & Collagen II degradation marker & ELISA [43] & SF & Nordic Bioscience, Herlev, Denmark \\
\hline $\mathrm{C} 1,2 \mathrm{C}$ & Type I/II collagen degradation & ELISA [43] & SF, Serum & IBEX, Montreal, Quebec, Canada \\
\hline CTXI & Type I collagen degradation & ELISA [44] & SF, Serum & Osteometer MediTech, Inc, Hawthorene, CA \\
\hline NTX & Bone formation marker & ELISA [45] & SF, Serum & Osteomark, Princeton, NJ \\
\hline CPII & Collagen II synthesis marker & ELISA [43] & SF, Serum & IBEX, Montreal, Quebec, Canada \\
\hline Osteocalcin & Bone synthesis marker & ELISA [43] & SF, Serum & Quidel Corporation, San Diego, CA \\
\hline$\beta$-Aspartate & Age dependant protein modification & Enzyme Assay [46] & SF, Serum & Promega, Madison, WI \\
\hline D-Asx & Age dependant protein modification & HPLC [22] & SF, Serum & Kraus laboratory In house \\
\hline D-Serine & Age dependant protein modification & HPLC [22] & SF, Serum & Kraus laboratory In house \\
\hline sCD44 & Cartilage marker & ELISA [47] & SF, Serum & eBioscience, Inc, San Diego, CA \\
\hline COMP & Cartilage matrix protein & ELISA [23] & SF, Serum & Kraus laboratory \\
\hline Tenascin C & Cartilage matrix protein & ELISA [48] & SF & IBL International GmbH, Toronto, ON, Canada \\
\hline Lubricin & Cartilage matrix protein & ELISA & SF & Pfizer In house \\
\hline MMP-3 & Proteolytic enzyme & ELISA [49] & SF, Serum & R\&D Systems, Inc., Minneapolis, Mn \\
\hline
\end{tabular}

COMP, cartilage oligomeric matrix protein; CRP, C-reactive protein; GAG, glycosaminoglycan. 


\section{Alanine-Arginine-Glycine-Serine (ARGS)-aggrecan ELISA} Synovial fluid samples were adjusted to contain $50 \mathrm{mM}$ Tris Acetate, $0.1 \mathrm{M} \mathrm{NaCl}$ and $5 \mathrm{mM} \mathrm{CaCl}_{2}, \mathrm{pH} 7.3$, and $1 \times$ protease inhibitor cocktail I (Calbiochem/EMD Chemicals, Gibbstown, NJ, USA). Samples were deglycosylated by treating with $0.2 \mathrm{U} / \mathrm{ml}$ chondroitinase $A B C$, $0.2 \mathrm{U} / \mathrm{ml}$ keratanase, and $0.02 \mathrm{U} / \mathrm{ml}$ keratanase II (Seikagaku America, Falmouth, MA, USA) at $37^{\circ} \mathrm{C}$ for two to three hours. Sample dilutions were then applied to microtiter plate wells coated with anti-human aggrecan mAb AHP0022 (Invitrogen, Carlsbad, CA, USA) and incubated for two hours at RT. After washing, horse radish peroxidase (HRP)-labeled anti-ARGS monoclonal antibody (mAb) BC-3 (Abcam, Cambridge, UK) was added to the wells, followed by incubation for 1.5 hours at RT, washing, and detection with 3,3', 5,5"-tetramethylbenzidine (TMB) One Component HRP substrate (BioFX Laboratories, Owings Mills, MD, USA). The concentration of ARGS-aggrecan for each sample was determined based on a standard curve generated using ADAMTS4digested human aggrecan as previously described [21].

\section{FA-846 fetal aggrecan sandwich ELISA}

FA-846 aggrecan was measured as per the manufacturer's (IBEX, Montreal, QC, Canada) instructions. Briefly, $50 \mu \mathrm{l}$ of assay buffer and either $50 \mu \mathrm{l}$ of diluted sample or standards were added to each well of a precoated plate and incubated at RT for 1.5 hours with shaking (600 to $700 \mathrm{rpm}$ ). The plate was washed six times using the supplied wash buffer before addition of $100 \mu \mathrm{l}$ of biotinylated FA- 846 antibody ( $50 \mu \mathrm{l}$ of stock diluted in the supplied buffer II) and incubated with shaking for 30 minutes at RT. Excess antibody was removed with a further six washes with the supplied wash buffer before the addition of $100 \mu \mathrm{l}$ of $5 \mathrm{pg} / \mathrm{ml}$ streptavidin-HRP diluted in buffer II and incubation for 30 minutes at RT with shaking. Excess streptavidin-HRP was removed with six washes before the addition of 100 $\mu \mathrm{l} /$ well of TMB reagent. Once developed, the TMB reaction was stopped using $100 \mu \mathrm{l} /$ well of stop solution and read at $450 \mathrm{~nm}$.

\section{Quantification of racemized amino acids}

Racemized Asx (Aspartate and Aspargine) and Serine concentrations in synovial fluid were quantified using a previously described high performance liquid chromatography (HPLC) approach developed and validated in our laboratory [22]. Briefly, purified proteins were acid hydrolyzed in $6 \mathrm{M} \mathrm{HCl}$ at $105^{\circ} \mathrm{C}$ for $8 \mathrm{~h}$. The resulting free $\mathrm{D}$ - and $\mathrm{L}$-amino acids were derivatized to fluorescent compounds by addition of o-phthaldialdehyde and $\mathrm{N}$-tert-butyloxycarbonyl-L-cysteine. The subsequent derivatives were separated by reversed-phase HPLC using a C18 column and mobile phases of $0.2 \mathrm{M}$ acetic acid adjusted to a $\mathrm{pH}$ of 6.0 and an acetonitrile gradient. The resulting peaks were quantified fluorometrically (ex340 nm, em440 nm) by comparison to commercially available pure D- and L-amino acids (Sigma-Aldrich, St. Louis, MO, USA).

\section{COMP ELISA}

Serum and synovial fluid COMP were quantified by ELISA using the mAb 16F12 for capture and biotinylated mAb $17 \mathrm{C} 10$ for detection as previously described [23] with the following minor modifications. Plates were blocked with 3\% BSA/PBS/0.02\% sodium azide for two hours. Synovial fluid was diluted 1:400 and 1:800. Streptavidin-alkaline phosphatase conjugate (ExtrAvadin, Sigma, St. Louis, MO, USA) was diluted $30,000 \times$ in $0.01 \% \mathrm{BSA} / \mathrm{PBS} / 0.02 \%$ sodium azide and the phosphatase substrate (4-nitrophenyl phosphate disodium salt hexahydrate, Sigma) was used as the detection agent. Plates were read at wavelength $405 \mathrm{~nm}$ after 20 minutes of incubation.

\section{Lubricin ELISA}

Synovial fluid samples were deglycosylated as described for the ARGS-aggrecan ELISA before sample dilutions were applied to microtiter plate wells coated with an anti-lubricin mAb (Clone 5; Pfizer, Cambridge, MA, USA) and incubated for one hour at RT. After washing, a second anti-lubricin mAb (HRP-lableled Clone 26; Pfizer) was added to the wells, followed by incubation for one hour at RT, washing, and detection with TMB One Component HRP substrate (BioFX Laboratories, Owings Mills, MD, USA). The concentration of lubricin for each sample was determined based on a standard curve generated using a recombinant human lubricin protein construct, LUB1 [24].

\section{Statistical methods}

Statistical analyses were performed using GraphPad Prism version 4.02 (GraphPad Software, Inc, La Jolla, CA, USA). Due to the small sample size used in this study it was not realistic to assume a Gaussian distribution and so all statistical tests used were non-parametric: for all correlations Spearman Rank correlation was used; for paired data Wilcoxon Signed Rank test was used. Samples for this study were derived from a pilot trial of a single injection, intra-articular anti-IL-1 therapy [20] and as described above, the drug and control groups were combined for purposes of statistical analysis.

\section{Results}

\section{Biomarker concentrations in the setting of acute knee} injury

To gain an understanding of the effect of joint injury on joint tissue turnover and pathology, we investigated 20 
biomarkers in synovial fluid and 13 in serum soon after acute knee injury and after a period of recovery but prior to surgery.

Initially we compared the baseline and follow-up data for each biomarker to determine whether there were any significant changes in biomarker concentrations between the two time points (Table 2). In synovial fluid $\left.{ }_{\mathrm{sf}}\right)$, we observed a significant decrease between the two collection time points for the inflammatory marker ${ }_{\text {sf }} \mathrm{CRP}(P=0.039)$, the cartilage superficial zone protein sf lubricin $(P=0.008)$ and the biomarkers of proteoglycan: ${ }_{\mathrm{sf}} \mathrm{GAG}(P=0.019)$ and the aggrecanase cleaved aggrecan marker ${ }_{\mathrm{sf}} \mathrm{ARGS}$ aggrecan $(P=0.004)$. We observed decreasing trends for the remaining inflammation and joint tissue biomarkers, ${ }_{s f} \mathrm{IL}-1 \beta(P=0.124)$, fetal aggrecan ${ }_{\mathrm{sf}} \mathrm{FA} 846(P=0.074)$ and ${ }_{\mathrm{sf}} \mathrm{COMP}(P=$ $0.055)$. In contrast, we observed significant increases between the two time points for several of the synovial fluid biomarkers of collagen turnover: $\mathrm{C}$-terminal crosslinked telopeptide type II collagen $\left({ }_{\mathrm{sf}} \mathrm{CT}\right.$ TII $)(P=0.012)$, ${ }_{\mathrm{sf}} \mathrm{C} 1,2 \mathrm{C}(P=0.039)$, C-terminal crosslinked telopeptide type I collagen $\left({ }_{\mathrm{sf}} \mathrm{CTxI}\right)(\mathrm{p}=0.004)$ and $\mathrm{N}$-terminal telopeptides of type I collagen $\left({ }_{\mathrm{sf}} \mathrm{NTx}\right)(P=0.008)$. While we observed small increases in the collagen degradation marker ${ }_{\mathrm{sf}} \mathrm{C} 2 \mathrm{C}$, the collagen synthesis marker ${ }_{\mathrm{sf}} \mathrm{CPII}$, and the bone synthesis marker ${ }_{\mathrm{sf}} \mathrm{O}$ steocalcin, these were not significant and may reflect the limitation of our small sample size. Finally we observed an increasing trend for the biomarker of protein age, $\mathrm{D}$-Serine $(P=0.055)$.

In the serum $(\mathrm{s})$ we observed fewer significant changes, with only ${ }_{\mathrm{s}}$ Osteocalcin $(P=0.032)$ demonstrating a significant decrease between the two time points, while both CTxI $(P=0.083)$ and NTx $(P=0.054)$ showed increasing trends with time, which were consistent with the observations in synovial fluid. We also used the complementary approach of Spearman Rank Correlation to analyze time from injury and synovial fluid biomarker concentration. Interestingly, we observed significant decreases with time for ${ }_{\mathrm{sf}} \mathrm{CRP}(P=$ $\left.0.041, \mathrm{r}_{\mathrm{s}}=-0.473\right),{ }_{\mathrm{sf}} \mathrm{GAG}\left(P=0.027, \mathrm{r}_{\mathrm{s}}=-0.506\right)$, ${ }_{s f}$ ARGS aggrecan $\left(P=0.003, \mathrm{r}_{\mathrm{s}}=-0.638\right),{ }_{\mathrm{sf}} \beta$-Aspartate $\left(P=0.025, \mathrm{r}_{\mathrm{s}}=-0.525\right)$ and ${ }_{\mathrm{sf}}$ lubricin $\left(P=0.027, \mathrm{r}_{\mathrm{s}}=\right.$ -0.506), while the collagen markers ${ }_{\mathrm{sf}} \mathrm{CTxII}(\mathrm{P}=0.002$, $\left.\mathrm{r}_{\mathrm{s}}=0.659\right)$ and ${ }_{\mathrm{sf}} \mathrm{C} 1,2 \mathrm{C}\left(P=0.005, \mathrm{r}_{\mathrm{s}}=0.613\right)$ demonstrated significant increases with time.

\section{Comparison of biomarkers in matched serum and synovial fluid}

To investigate whether the biomarker values measured in serum behaved as surrogates for the concentrations found within the signal knee after acute injury, we compared biomarker concentrations in synovial fluid and serum from the matched samples collected from the same patients. Due to assay sensitivity and specificity, we were able to measure 12 of the 20 synovial fluid biomarkers in matched serum and synovial fluid samples (Table 2). We hypothesized that biomarkers produced in the injured signal knee would have significantly higher concentrations in the synovial fluid than in the circulating serum. When we compared the concentrations of the 12 biomarkers measured in both fluids, seven demonstrated significantly higher concentrations in the synovial fluid than serum: IL-1 $\beta(P<0.0001)$, FA846 $(P=0.0001)$, CTxI $(P=0.0002), \operatorname{NTx}(P=$ $0.012)$, Osteocalcin $(P=0.012)$, COMP $(P=0.0001)$ and MMP-3 $(P=0.0001)$. The biggest differences between synovial fluid and serum were observed for MMP-3 and COMP with fold differences of 738.8 and 21.2 respectively. Smaller fold differences were observed for FA846 (5.9x), IL-1 $\beta$ (4.3×), CTxI (1.6×), NTx (1.2×) and osteocalcin $(1.2 \times)$. The inflammatory marker CRP, produced in the liver, showed significantly higher concentrations $(P=0.012)$ in the serum than in synovial fluid $(3.5 \times)$. It is of note that CRP is not an OA specific marker, it is an acute phase protein and upregulated in many different conditions, which limits its specificity. We also observed significantly higher concentrations of $\mathrm{C} 1,2 \mathrm{C}(P=0.005)$ in the serum suggesting a systemic source or rapid clearance from the joint for this biomarker (1.8x).

To further investigate the utility of the serum biomarkers to reflect signal knee synovial fluid concentrations, we performed Spearman Rank correlations between the matched synovial fluid and serum samples. Of the seven biomarkers with significantly higher concentrations in synovial fluid than serum, the concentrations of four biomarkers were found to correlate between the two fluids; CTxI $(P=0.0002)$, NTx $(P<0.0001)$, osteocalcin $(P=0.0002)$ and MMP-3 $(P=0.038)$ (Table 2$)$. These data strongly suggest a signal knee source of these biomarkers and the ability of a serum concentration to reflect early signal knee events following acute injury. Of note, the acute phase reactant protein, CRP, demonstrated the reverse pattern; CRP concentrations in serum exceeded those in synovial fluid and there was a significant correlation $(P=0.002)$ between the serum and synovial fluid concentration compatible with passive diffusion of CRP into the synovial fluid, suggesting a systemic response to acute injury rather than a signal knee specific response. In the acute injury phase, the duration and/or level of elevation of CRP in the serum may be a useful indicator of extent and severity of tissue injury but this would require correlation with arthroscopic or MRI assessments of joint inflammation and injury.

\section{Discussion}

It is important to understand the amount and type of joint damage after acute injury to identify novel 
Table 2 Biomarker concentrations at baseline and follow-up in serum and synovial fluid after acute knee injury

\begin{tabular}{|c|c|c|c|c|c|c|c|c|}
\hline \multirow[b]{2}{*}{ Biomarker } & \multicolumn{3}{|c|}{ Synovial Fluid Levels } & \multicolumn{3}{|c|}{ Serum Levels } & \multicolumn{2}{|c|}{ Serum vs Synovial Fluid } \\
\hline & $\begin{array}{l}\text { Baseline } \\
\text { Mean } \\
\pm \text { SD }\end{array}$ & $\begin{array}{l}\text { Follow } \\
\text { Up Mean } \\
\pm S D\end{array}$ & $P$-value & $\begin{array}{l}\text { Baseline } \\
\text { Mean } \\
\pm S D\end{array}$ & $\begin{array}{l}\text { Follow } \\
\text { Up Mean } \\
\pm S D\end{array}$ & P-value & $\begin{array}{c}\text { Mean Ratio (synovial } \\
\text { fluid/serum levels) } \pm \text { SD, } \\
P \text {-value }\end{array}$ & $\begin{array}{c}\text { Correlation (between serum } \\
\text { and synovial fluid levels), } P \text { - } \\
\text { value }\end{array}$ \\
\hline \multicolumn{9}{|c|}{ Inflammation markers } \\
\hline $\begin{array}{c}\mathrm{IL}-1 \beta(\mathrm{pg} / \\
\mathrm{ml})\end{array}$ & $\begin{array}{l}1.02 \pm \\
0.66\end{array}$ & $\begin{array}{l}0.61 \pm \\
0.22\end{array}$ & $P=0.124$ & $\begin{array}{c}0.17 \pm \\
0.06\end{array}$ & $\begin{array}{l}0.24 \pm \\
0.12\end{array}$ & $P=0.102$ & $\uparrow 4.3 \pm 2.1, p<0.0001$ & $r_{s}=0.358, P=0.123$ \\
\hline $\begin{array}{l}\text { CRP ( } \mu \mathrm{g} / \\
\mathrm{ml})\end{array}$ & $\begin{array}{l}1.67 \pm \\
1.28\end{array}$ & $\begin{array}{c}0.68 \pm \\
0.64\end{array}$ & $P=0.039$ & $\begin{array}{c}3.18 \pm \\
2.93\end{array}$ & $\begin{array}{l}1.78 \pm \\
2.10\end{array}$ & $P=0.102$ & $\downarrow 3.5 \pm 4.2, p=0.012$ & $r_{s}=0.658, P=0.002$ \\
\hline \multicolumn{9}{|c|}{ Proteoglycan markers } \\
\hline $\begin{array}{c}\mathrm{GAG}(\mu \mathrm{g} / \\
\mathrm{ml})\end{array}$ & $\begin{array}{c}330.7 \pm \\
203.2\end{array}$ & $\begin{array}{c}170.2 \pm \\
45.9\end{array}$ & $P=0.008$ & - & - & - & - & - \\
\hline $\begin{array}{l}\text { ARGS } \\
\text { aggrecan } \\
(\mu \mathrm{g} / \mathrm{ml})\end{array}$ & $\begin{array}{c}230.7 \pm \\
236.7\end{array}$ & $\begin{array}{c}63.2 \pm \\
54.0\end{array}$ & $P=0.004$ & - & - & - & - & - \\
\hline $\begin{array}{l}\text { FA846 } \\
(\mathrm{ng} / \mathrm{ml})\end{array}$ & $\begin{array}{c}1134.0 \pm \\
158.1\end{array}$ & $\begin{array}{c}886.5 \pm \\
295.8\end{array}$ & $P=0.074$ & $\begin{array}{c}31.2 \pm \\
35.1\end{array}$ & $\begin{array}{c}32.4 \pm \\
43.8\end{array}$ & $P=0.520$ & $\uparrow 59.1 \pm 6.3, p=0.0001$ & $r_{s}=-0.179, P=0.464$ \\
\hline $\begin{array}{c}\text { CS846 } \\
(\mathrm{ng} / \mathrm{ml})^{*}\end{array}$ & - & - & - & $\begin{array}{l}72.3 \pm \\
139.2\end{array}$ & $\begin{array}{l}58.1 \pm \\
131.6\end{array}$ & $P=0.413$ & - & - \\
\hline \multicolumn{9}{|l|}{ Collagen markers } \\
\hline $\begin{array}{c}\text { C2C (ng/ } \\
\text { ml) }\end{array}$ & $\begin{array}{c}184.1 \pm \\
37.6\end{array}$ & $\begin{array}{c}208.9 \pm \\
56.3\end{array}$ & $P=0.301$ & $\begin{array}{c}226.5 \pm \\
34.8\end{array}$ & $\begin{array}{c}216.3 \pm \\
49.2\end{array}$ & $P=0.700$ & $\downarrow 1.2 \pm 0.5, p=0.232$ & $r_{s}=-0.463, P=0.046$ \\
\hline $\begin{array}{c}\text { CTx\| }(\mu \mathrm{g} / \\
\mathrm{L})\end{array}$ & $\begin{array}{c}0.59 \pm \\
0.58\end{array}$ & $\begin{array}{l}1.09 \pm \\
0.63\end{array}$ & $P=0.012$ & - & - & - & - & - \\
\hline $\begin{array}{c}C 1,2 C \\
(\mu \mathrm{g} / \mathrm{ml})\end{array}$ & $\begin{array}{c}0.28 \pm \\
0.10\end{array}$ & $\begin{array}{l}0.37 \pm \\
0.08\end{array}$ & $P=0.039$ & $\begin{array}{c}0.53 \pm \\
0.18\end{array}$ & $\begin{array}{c}0.51 \pm \\
0.19\end{array}$ & $P=0.638$ & $\downarrow 1.8 \pm 1.2, p=0.005$ & $r_{s}=0.209, P=0.391$ \\
\hline $\begin{array}{c}\text { CTxl (ng/ } \\
\text { ml) }\end{array}$ & $\begin{array}{c}0.75 \pm \\
0.39\end{array}$ & $\begin{array}{l}1.23 \pm \\
0.67\end{array}$ & $P=0.004$ & $\begin{array}{c}0.52 \pm \\
0.32\end{array}$ & $\begin{array}{c}0.66 \pm \\
0.31\end{array}$ & $P=0.083$ & $\uparrow 1.6 \pm 0.5, p=0.0002$ & $r_{s}=0.819, P<0.0001$ \\
\hline $\begin{array}{c}\text { NTx (nM } \\
\text { BCE) }\end{array}$ & $\begin{array}{c}15.58 \pm \\
4.37\end{array}$ & $\begin{array}{c}19.64 \pm \\
7.78\end{array}$ & $P=0.008$ & $\begin{array}{c}18.67 \pm \\
6.92\end{array}$ & $21.6 \pm 4.2$ & $P=0.054$ & $\uparrow 1.2 \pm 0.2, p=0.012$ & $r_{s}=0.828, P<0.0001$ \\
\hline $\begin{array}{l}\text { CPII (ng/ } \\
\text { ml) }\end{array}$ & $\begin{array}{c}308.1 \pm \\
257.4\end{array}$ & $\begin{array}{c}318.3 \pm \\
185.1\end{array}$ & $P=0.820$ & $\begin{array}{c}365.2 \pm \\
181.5\end{array}$ & $\begin{array}{c}288.2 \\
\pm 106.8\end{array}$ & $P=0.102$ & $\uparrow 1.3 \pm 0.9, p=0.976$ & $r_{s}=-0.102, P=0.679$ \\
\hline $\begin{array}{l}\text { Osteocalcin } \\
(\mathrm{ng} / \mathrm{ml})\end{array}$ & $\begin{array}{c}15.43 \pm \\
4.99\end{array}$ & $\begin{array}{c}17.08 \pm \\
6.16\end{array}$ & $P=0.301$ & $\begin{array}{c}19.91 \pm \\
8.54\end{array}$ & $16.3 \pm 5.6$ & $P=0.032$ & $\uparrow 1.2 \pm 0.3, p=0.012$ & $r_{s}=0.747, P=0.0002$ \\
\hline \multicolumn{9}{|c|}{ Post-translational markers of protein age } \\
\hline $\begin{array}{c}\beta- \\
\text { Aspartate } \\
(\mu \mathrm{M})\end{array}$ & $\begin{array}{c}0.94 \pm \\
0.32\end{array}$ & $\begin{array}{c}0.76 \pm \\
0.37\end{array}$ & $P=0.129$ & - & - & - & - & - \\
\hline $\begin{array}{c}\text { D-Asx (D/ } \\
\mathrm{D}+\mathrm{L})\end{array}$ & $\begin{array}{c}0.018 \pm \\
0.001\end{array}$ & $\begin{array}{c}0.019 \pm \\
0.002\end{array}$ & $P=0.423$ & - & - & - & - & - \\
\hline $\begin{array}{l}\text { D-Serine } \\
(\mathrm{D} / \mathrm{D}+\mathrm{L})\end{array}$ & $\begin{array}{c}0.002 \pm \\
0.001\end{array}$ & $\begin{array}{c}0.003 \pm \\
0.001\end{array}$ & $P=0.055$ & - & - & - & - & - \\
\hline \multicolumn{9}{|l|}{ Other Biomarkers } \\
\hline $\begin{array}{c}\mathrm{sCD} 44 \\
(\mathrm{ng} / \mathrm{ml})^{*}\end{array}$ & $\begin{array}{c}128.1 \pm \\
49.0\end{array}$ & $\begin{array}{c}105.0 \pm \\
28.2\end{array}$ & $P=0.250$ & $\begin{array}{c}115.9 \pm \\
26.9\end{array}$ & $\begin{array}{c}110.7 \pm \\
39.0\end{array}$ & $P=0.820$ & $\uparrow 1.1 \pm 0.4, p=0.922$ & $r_{s}=0.301, P=0.226$ \\
\hline $\begin{array}{l}\text { COMP } \\
(\mu \mathrm{g} / \mathrm{ml})\end{array}$ & $\begin{array}{c}140.9 \pm \\
65.4\end{array}$ & $\begin{array}{c}99.1 \pm \\
32.3\end{array}$ & $P=0.055$ & $8.6 \pm 4.1$ & $8.0 \pm 4.4$ & $P=0.278$ & $\uparrow 21.2 \pm 15.3, P=0.0001$ & $r_{s}=-0.326, P=0.173$ \\
\hline $\begin{array}{l}\text { Tenascin } \\
\text { C (ng/ml) }\end{array}$ & $\begin{array}{c}813.2 \pm \\
428.6\end{array}$ & $908 \pm 599$ & $P=0.570$ & - & - & - & - & - \\
\hline $\begin{array}{l}\text { Lubricin } \\
\text { (nM equ) }\end{array}$ & $\begin{array}{c}390.4 \pm \\
159.6\end{array}$ & $\begin{array}{c}215.9 \pm \\
59.0\end{array}$ & $P=0.008$ & - & - & - & - & - \\
\hline $\begin{array}{l}\text { MMP-3 } \\
(\mathrm{ng} / \mathrm{ml})\end{array}$ & $\begin{array}{c}29.02 \pm \\
20.84\end{array}$ & $\begin{array}{c}30.89 \pm \\
26.56\end{array}$ & $\begin{array}{c}P= \\
0.910\end{array}$ & $\begin{array}{l}0.05 \pm \\
0.02\end{array}$ & $\begin{array}{c}0.04 \pm \\
0.02\end{array}$ & $\begin{array}{c}P= \\
0.148\end{array}$ & $\uparrow 738.8 \pm 602.5, P=0.0001$ & $r_{s}=0.479, P=0.038$ \\
\hline
\end{tabular}

Results represent mean \pm SD data for $n=9$ patients for synovial fluid values and for serum $n=11$ or $n=9$ for * marked biomarkers due to sample depletion. Non-parametric paired analyses by Wilcoxon Signed Rank test were performed to evaluate for significant differences between baseline and follow up time points and between serum and synovial fluid values. Non parametric Spearman Rank correlations $\left(r_{s}\right)$ were performed to determine correlations between synovial fluid and serum and the ratios reported are mean ratios \pm SD. 
therapeutic strategies that could be employed to better treat the symptoms and reduce the future risk of posttraumatic OA development. In this study we investigated the changes in biomarker concentrations at the time of sports-related acute knee injury and after a short period of recovery prior to surgery in 11 young patients with a mean age of 23 years. The patients were all part of a small randomized placebo-controlled pilot study of IL-Ra to determine the feasibility and establish the methodology for future clinical trials in acute joint injury. The initial samples were obtained prior to IL-1Ra injection and the second set of samples was obtained a mean four weeks later. No statistical difference was observed between the treatment and placebo arms for any of the biomarkers presented in this paper although we acknowledge that a sample of this size may have limited power to detect such differences. However, we believe it is reasonable to expect that these effects on the biomarker levels would be minimal because a single dose of IL-1Ra has a very short in vivo half-life, estimated at four to six hours after bolus subcutaneous injection [25]. We investigated a total of 21 different biomarkers representing a wide range of joint relevant molecules in both synovial fluid and serum to better understand the changes which occur after acute injury and to identify biomarkers which might be most useful for following the effectiveness of future disease modifying protocols.

The investigation of several different classes of biomarkers after acute injury demonstrated that the proteoglycan biomarkers ( ${ }_{s f}$ GAG, ${ }_{\text {sf }}$ ARGS aggrecan and ${ }_{\text {sf }}$ FA846) decreased with time from injury which mirrored the inflammation biomarker ${ }_{\mathrm{sf}} \mathrm{CRP}$ and ${ }_{\mathrm{sf}}$ lubricin. A decreasing trend was also observed for ${ }_{\mathrm{sf}} \mathrm{COMP}$, while interestingly ${ }_{\mathrm{sf}} \mathrm{MMP}-3 \mathrm{did}$ not change over time. In contrast, all the collagen and bone biomarkers increased with time from injury. Taken together, these results demonstrate that the cartilage within the injured joint responds to the initial acute injury with a wave of proteoglycan and non-collagenous protein loss. However, as the concentrations of proteoglycans and small cartilage molecules declined, there was apparent onset of collagen damage with a rise in synovial fluid collagen biomarkers. These in vivo findings after acute injury are analogous to the temporal patterns of matrix epitope release in vitro from cartilage explants stimulated with proinflammatory cytokines in which there is an initial loss of proteoglycan followed by collagen loss [26]. It has long been known from animal studies $[27,28]$ that the loss of proteoglycan is reversible while once the collagen is lost, the cartilage is irreparably damaged [29]. Since these data show significant cartilage collagen epitope loss in vivo within even the first month after injury, it would appear that critical and possibly irreversible damage is sustained within weeks of severe knee injury with an ACL tear. These data suggest the possible need for very early intervention to prevent post-traumatic-osteoarthritis. More detailed studies are required to better characterize these early changes and to link them to the future risk of post-traumatic OA known from previous studies to be $50 \%$ by 10 to 15 years following ACL injury $[1,3]$.

The most likely cause of this observed early cartilage and joint damage after acute injury is through the effect of pro-inflammatory cytokines released into the synovial fluid. This observed inflammatory driven damage matches that observed in pro-inflammatory cytokineinduced cartilage degeneration in explant models [26] and the catabolic processes observed in rheumatoid arthritis and preclinical animal models of OA. These observations suggest that some of the already existing small molecules that have demonstrated chondroprotective effects in vitro, in animal models and in humans with rheumatoid arthritis may constitute new treatment strategies to prevent the irreversible cartilage damage in the form of collagen loss after acute injury and thereby offer the hope of preventing future onset of injury related OA. These include: the biologic anti-cytokine therapies directed towards IL- $1 \alpha$, TNF $\alpha$ or IL- 6 that are successful rheumatoid arthritis therapies [30]; p38 mitogen activated protein kinases (MAPK) pathway inhibitors, protective in a rat model of OA [31,32] and in explant culture [33]; statins that inhibit cartilage breakdown by reducing protein prenylation $[34,35]$; and sulfazalazine that can inhibit collagenase production by inhibiting the NFkB pathway in cartilage explant models [36]. Direct inhibition of catabolic enzymes may also be a viable short term target for cartilage and joint protection after acute injury. Inhibition of proteoglycan loss has been shown to be effective at preventing OA in animals [37-39] while inhibition of the collagen degrading collagenase enzymes can protect cartilage from irreversible collagen loss [40]. Any of these potential therapies could be administered early after acute injury for a short period of time to prevent the initial and potentially irreparable cartilage and joint damage which occurs after acute injury.

In this study we also compared the concentrations of different biomarkers in the synovial fluid and the serum to determine how the serum concentrations reflect the changes in the signal knee. These data are important for future clinical trials as measuring biomarkers in the serum is easier than obtaining serial synovial fluid samples. Only MMP-3 and the bone biomarkers, CTxI, NTx and osteocalcin demonstrated a significant correlation between serum and synovial fluid concentrations suggesting that these serum biomarkers may accurately reflect the activity in the signal knee. The lack of correlation between the serum and synovial fluid concentrations 
for many of the standard biomarkers may be due to their rapid clearance from the joint or systemic circulation, or significant confounding of serum concentrations by other sources of biomarker epitopes. While there has been much research using these biomarkers (see comprehensive recent reviews by van Spil et al. [41] and Kraus et al. [42]), more research is required to better profile both the currently available biomarkers and to develop more specific biomarkers which are less sensitive to systemic contributions.

\section{Conclusions}

The results presented in this manuscript demonstrate that there is significant and measurable cartilage and bone damage after acute knee injury. We also noted that the release of biomarkers from cartilage matches the profile observed from in vitro cartilage explants models treated with pro-inflammatory cytokines. This similarity between the damage which occurs in acute injury and the cartilage explant models suggests that much of the chondroprotective research performed in cartilage explant systems could be directly translated to the treatment of acute injury to reduce or even prevent early cartilage damage, thereby potentially reducing the risk of later early onset OA.

\begin{abstract}
Abbreviations
ADAMTS: A Disintegrin And Metalloprotease with ThromboSpondin motifs; ACL: anterior cruciate ligament; ANOVA: ANOVA Analysis of Variance; ARGS: Alanine-Arginine-Glycine-Serine; Asx, aspartate and asparagine; COMP: cartilage oligomeric matrix protein; CRP: C-Reactive protein; CTxl: C-terminal crosslinked telopeptide type I collagen; ${ }_{s} \mathrm{CTXIl}$ : C-terminal crosslinked telopeptide type II collagen; GAG: glycosaminoglycan; HPLC: high performance liquid chromatography; HRP: horse radish peroxidase; IL: interleukin; IL-1Ra: IL-1 receptor antagonist; mAb: monoclonal antibody; MAPK: mitogen activated protein kinase; MMP: matrix metalloproteinase; MRI: magnetic resonance imaging; ${ }_{\text {sf }} \mathrm{NTx}$ : N-terminal telopeptides of type I collagen; OA: osteoarthritis; RT: room temperature; TIMP: tissue inhibitor of metalloproteinase; TMB: 3,3', 5,5"-tetramethylbenzidine; TNF: tumor necrosis factor; v/v: volume/volume.
\end{abstract}

\section{Acknowledgements}

Funding for this study was provided by the NIH/NIA Claude D. Pepper OAIC 5P30 AG028716. We would like to acknowledge the assistance of Janet Huebner for advice and for assistance in this project. We would like to acknowledge Weilan Zeng, Priya Chockalingam and Weiyong Sun from the Tissue Repair Research Unit, Pfizer, for running the lubricin, ARGS aggrecan, total aggrecan and Tenascin C assays. We wish to thank Dr. Vladimir Vilim for his kind gift of anti-COMP monoclonal antibodies (16F12 and 17C10). We wish to thank IBEX for their gift of kits for testing FA846.

\section{Author details}

${ }^{1}$ Division of Rheumatology, Department of Medicine, Duke University, Genome Science Research Building I, 905 South LaSalle Street, Durham, NC 27710, USA. ${ }^{2}$ Tissue Repair Research Unit, BioTherapeutics Division, Pfizer Inc. 200 Cambridge Park Drive, Cambridge, MA 02140, USA

\section{Authors' contributions}

JC, TS and CRF performed and/or coordinated biomarker analyses. JC performed statistical analyses and drafted the manuscript. VBK designed and supervised all aspects of the study. All authors participated in manuscript editing. All authors read and approved the final manuscript.

\section{Competing interests}

JC, TS and VBK declare that they have no competing interests. CRF is an employee of and holds stock/stock options in Pfizer.

Received: 1 June 2010 Revised: 1 September 2010

Accepted: 31 December 2010 Published: 31 December 2010

\section{References}

1. Lohmander LS, Englund PM, Dahl LL, Roos EM: The long-term consequence of anterior cruciate ligament and meniscus injuries: osteoarthritis. Am J Sports Med 2007, 35:1756-1769.

2. Frobell RB, Roos HP, Roos EM, Hellio Le Graverand MP, Buck R, TamezPena J, Totterman S, Boegard T, Lohmander LS: The acutely ACL injured knee assessed by MRI: are large volume traumatic bone marrow lesions a sign of severe compression injury? Osteoarthritis Cartilage 2008, 16:829-836.

3. Roos EM: Joint injury causes knee osteoarthritis in young adults. Curr Opin Rheumatol 2005, 17:195-200.

4. Gelber AC, Hochberg MC, Mead LA, Wang NY, Wigley FM, Klag MJ: Joint injury in young adults and risk for subsequent knee and hip osteoarthritis. Ann Intern Med 2000, 133:321-328.

5. Brown TD, Johnston RC, Saltzman CL, Marsh JL, Buckwalter JA: Posttraumatic osteoarthritis: a first estimate of incidence, prevalence, and burden of disease. J Orthop Trauma 2006, 20:739-744.

6. Buckwalter JA, Saltzman CL, Brown T: The impact of osteoarthritis: implication for research. Clin Orthop Relat Res 2004, 427:S6-15.

7. Chaudhari AM, Briant PL, Bevill SL, Koo S, Andriacchi TP: Knee kinematics, cartilage morphology, and osteoarthritis after ACL injury. Med Sci Sports Exerc 2008, 40:215-222

8. Irie $\mathrm{K}$, Uchiyama $\mathrm{E}$, Iwaso $\mathrm{H}$ : Intraarticular inflammatory cytokines in acute anterior cruciate ligament injured knee. Knee 2003, 10:93-96.

9. Lohmander LS, Atley LM, Pietka TA, Eyre DR: The release of crosslinked peptides from type II collagen into human synovial fluid is increased soon after joint injury and in osteoarthritis. Arthritis Rheum 2003, 48:3130-3139.

10. Lohmander LS, Dahlberg L, Ryd L, Heinegard D: Increased levels of proteoglycan fragments in knee joint fluid after injury. Arthritis Rheum 1989, 32:1434-1442.

11. Lohmander LS: The release of aggrecan fragments into synovial fluid after joint injury and in osteoarthritis. J Rheumatol Supp/ 1995, 43:75-77.

12. Lohmander LS, Hoerrner LA, Dahlberg L, Roos H, Bjornsson S, Lark MW: Stromelysin, tissue inhibitor of metalloproteinases and proteoglycan fragments in human knee joint fluid after injury. J Rheumatol 1993, 20:1362-1368.

13. Lohmander LS, Hoerrner LA, Lark MW: Metalloproteinases, tissue inhibitor, and proteoglycan fragments in knee synovial fluid in human osteoarthritis. Arthritis Rheum 1993, 36:181-189.

14. Lohmander LS, Neame PJ, Sandy JD: The structure of aggrecan fragments in human synovial fluid. Evidence that aggrecanase mediates cartilage degradation in inflammatory joint disease, joint injury, and osteoarthritis. Arthritis Rheum 1993, 36:1214-1222.

15. Lohmander LS, Roos H, Dahlberg L, Hoerrner LA, Lark MW: Temporal patterns of stromelysin-1, tissue inhibitor, and proteoglycan fragments in human knee joint fluid after injury to the cruciate ligament or meniscus. J Orthop Res 1994, 12:21-28.

16. Lohmander LS, Saxne T, Heinegard DK: Release of cartilage oligomeric matrix protein (COMP) into joint fluid after knee injury and in osteoarthritis. Ann Rheum Dis 1994, 53:8-13.

17. Dahlberg L, Roos H, Saxne T, Heinegard D, Lark MW, Hoerrner LA, Lohmander LS: Cartilage metabolism in the injured and uninjured knee of the same patient. Ann Rheum Dis 1994, 53:823-827.

18. Carney SL, Billingham ME, Muir H, Sandy JD: Demonstration of increased proteoglycan turnover in cartilage explants from dogs with experimental osteoarthritis. J Orthop Res 1984, 2:201-206.

19. Ratcliffe A, Billingham ME, Saed-Nejad F, Muir H, Hardingham TE: Increased release of matrix components from articular cartilage in experimental canine osteoarthritis. J Orthop Res 1992, 10:350-358.

20. Kraus VB, Birmingham J, Stabler T, Taylor DC, Moorman CT III, Garrett WE, Toth A: Intraarticular IL1-Ra after acute knee injury decreases biomarkers of inflammation and improves pain and function. Osteoarthritis Cartilage 2010 
21. Chockalingam PS, Sun W, Rivera-Bermudez MA, Zeng W, Dufield DR Larsson S, Lohmander LS, Flannery CR, Glasson SS, Georgiadis KE, Morris EA: Elevated aggrecanase activity in a rat model of joint injury is attenuated by an aggrecanase specific inhibitor. Osteoarthritis Cartilage 2011, 19:315-323.

22. Stabler TV, Byers SS, Zura RD, Kraus VB: Amino acid racemization reveals differential protein turnover in osteoarthritic articular and meniscal cartilages. Arthritis Res Ther 2009, 11:R34.

23. Vilim V, Olejarova M, Machacek S, Gatterova J, Kraus VB, Pavelka K: Serum levels of cartilage oligomeric matrix protein (COMP) correlate with radiographic progression of knee osteoarthritis. Osteoarthritis Cartilage 2002, 10:707-713.

24. Flannery $C R$, Zollner $R$, Corcoran $C$, Jones $A R$, Root $A$, Rivera-Bermudez MA Blanchet T, Gleghorn JP, Bonassar LJ, Bendele AM, Morris EA, Glasson SS: Prevention of cartilage degeneration in a rat model of osteoarthritis by intraarticular treatment with recombinant lubricin. Arthritis Rheum 2009, 60:840-847.

25. Kineret ${ }^{\circledR}$ (anakinra) (summary of product characteristics). [http://www. kineret-eu.com/download/en/kineret_summary_of_product_characteristics. pdf].

26. Cawston TE, Ellis AJ, Humm G, Lean E, Ward D, Curry V: Interleukin-1 and oncostatin $M$ in combination promote the release of collagen fragments from bovine nasal cartilage in culture. Biochem Biophys Res Commun 1995, 215:377-385

27. Page Thomas DP, King B, Stephens T, Dingle JT: In vivo studies of cartilage regeneration after damage induced by catabolin/interleukin-1. Ann Rheum Dis 1991, 50:75-80.

28. Thomas L: Reversible collapse of rabbit ears after intravenous papain, and prevention of recovery by cortisone. J Exp Med 1956, 104:245-252.

29. Jubb RW, Fell HB: The breakdown of collagen by chondrocytes. J Pathol 1980, 130:159-167

30. Isaacs JD: The changing face of rheumatoid arthritis: sustained remission for all? Nat Rev Immunol 2010, 10:605-611.

31. Badger AM, Griswold DE, Kapadia R, Blake S, Swift BA, Hoffman SJ, Stroup GB, Webb E, Rieman DJ, Gowen M, Boehm JC, Adams JL, Lee JC: Disease-modifying activity of SB 242235, a selective inhibitor of p38 mitogen-activated protein kinase, in rat adjuvant-induced arthritis. Arthritis Rheum 2000, 175-183.

32. Brown KK, Heitmeyer SA, Hookfin EB, Hsieh L, Buchalova M, Taiwo YO, Janusz MJ: P38 MAP kinase inhibitors as potential therapeutics for the treatment of joint degeneration and pain associated with osteoarthritis. J Inflamm (Lond) 2008, 5:22.

33. Hui W, Litherland GJ, Jefferson M, Barter MJ, Elias MS, Cawston TE, Rowan $A D$, Young DA: Lithium protects cartilage from cytokine-mediated degradation by reducing collagen-degrading MMP production via inhibition of the P38 mitogen-activated protein kinase pathway. Rheumatology (Oxford) 2010, 49:2043-2053.

34. Barter MJ, Hui W, Lakey RL, Catterall JB, Cawston TE, Young DA: Lipophilic statins prevent matrix metalloproteinase-mediated cartilage collagen breakdown by inhibiting protein geranylgeranylation. Ann Rheum Dis 2010, 69:2189-2198.

35. Sverdrup FM, Yates MP, Vickery LE, Klover JA, Song LR, Anglin CP, Misko TP: Protein geranylgeranylation controls collagenase expression in osteoarthritic cartilage. Osteoarthritis Cartilage 2010, 18:948-955.

36. Lakey RL, Cawston TE: Sulfasalazine blocks the release of proteoglycan and collagen from cytokine stimulated cartilage and down-regulates metalloproteinases. Rheumatology (Oxford) 2009, 48:1208-1212.

37. Glasson SS, Askew R, Sheppard B, Carito B, Blanchet T, Ma HL, Flannery CR, Peluso D, Kanki K, Yang Z, Majumdar MK, Morris EA: Deletion of active ADAMTS5 prevents cartilage degradation in a murine model of osteoarthritis. Nature 2005, 434:644-648.

38. Glasson SS, Askew R, Sheppard B, Carito BA, Blanchet T, Ma HL, Flannery CR, Kanki K, Wang E, Peluso D, Yang Z, Majumdar MK, Morris EA: Characterization of and osteoarthritis susceptibility in ADAMTS-4knockout mice. Arthritis Rheum 2004, 50:2547-2558.

39. Karsdal MA, Madsen SH, Christiansen C, Henriksen K, Fosang AJ, Sondergaard BC: Cartilage degradation is fully reversible in the presence of aggrecanase but not matrix metalloproteinase activity. Arthritis Res Ther 2008, 10:R63.

40. Catterall JB, Cawston TE: Drugs in development: bisphosphonates and metalloproteinase inhibitors. Arthritis Res Ther 2003, 5:12-24.
41. van Spil WE, DeGroot J, Lems WF, Oostveen JC, Lafeber FP: Serum and urinary biochemical markers for knee and hip-osteoarthritis: a systematic review applying the consensus BIPED criteria. Osteoarthritis Cartilage 2010, 18:605-612.

42. Kraus VB, Burnett B, Coindreau J, Cotrell S, Eyre DR, Gendreau M, Gardiner J, Garnero P, Hardin J, Henrotin Y, Heinegard D, Ko A, Lohmander LS, Matthews G, Menetski J, Moskowitz R, Persiani S, Poole AR, Rousseau JC, Todman M: Application of biomarkers in the development of drugs intended for the treatment of osteoarthritis: OARSI FDA Osteoarthritis Biomarkers Working Group. Osteoarthritis Cartilage 2010.

43. Kong SY, Stabler TV, Criscione LG, Elliott AL, Jordan JM, Kraus VB: Diurnal variation of serum and urine biomarkers in patients with radiographic knee osteoarthritis. Arthritis Rheum 2006, 54:2496-2504.

44. Mazieres B, Hucher M, Zaim M, Garnero P: Effect of chondroitin sulphate in symptomatic knee osteoarthritis: a multicentre, randomised, doubleblind, placebo-controlled study. Ann Rheum Dis 2007, 66:639-645.

45. Wilkinson JM, Stockley I, Peel NF, Hamer AJ, Elson RA, Barrington NA, Eastell R: Effect of pamidronate in preventing local bone loss after total hip arthroplasty: a randomized, double-blind, controlled trial. J Bone Miner Res 2001, 16:556-564.

46. Catterall JB, Barr D, Bolognesi M, Zura RD, Kraus VB: Post-translational aging of proteins in osteoarthritic cartilage and synovial fluid as measured by isomerized aspartate. Arthritis Res Ther 2009, 11:R55.

47. Cao J, Li S, Shi Z, Yue Y, Sun J, Chen J, Fu Q, Hughes CE, Caterson B: Articular cartilage metabolism in patients with Kashin-Beck Disease: an endemic osteoarthropathy in China. Osteoarthritis Cartilage 2008, 16:680-688.

48. Hasegawa M, Nakoshi Y, Tsujii M, Sudo A, Masuda H, Yoshida T, Uchida A: Changes in biochemical markers and prediction of effectiveness of intraarticular hyaluronan in patients with knee osteoarthritis. Osteoarthritis Cartilage 2008, 16:526-529.

49. van Kuijk AW, DeGroot J, Koeman RC, Sakkee N, Baeten DL, Gerlag DM, Tak PP: Soluble biomarkers of cartilage and bone metabolism in early proof of concept trials in psoriatic arthritis: effects of adalimumab versus placebo. PLoS One 2010, 5:pii: 12556.

doi:10.1186/ar3216

Cite this article as: Catterall et al:: Changes in serum and synovial fluid biomarkers after acute injury (NCT00332254). Arthritis Research \& Therapy 2010 12:R229.

\section{Submit your next manuscript to BioMed Central and take full advantage of:}

- Convenient online submission

- Thorough peer review

- No space constraints or color figure charges

- Immediate publication on acceptance

- Inclusion in PubMed, CAS, Scopus and Google Scholar

- Research which is freely available for redistribution

Submit your manuscript at www.biomedcentral.com/submit
C Biomed Central 